\title{
KAJIAN PEMANFAATAN INTERNET SEBAGAI SUMBER BAHAN AJAR BAGI GURU MI AL MADARIJUT JAKARTA
}

\author{
Rudi Hermawan \\ Program Studi Informatika, Universitas Indraprasta PGRI Jakarta \\ Email : wowor99@gmail.com
}

\begin{abstract}
Abstrak
Seiring dengan kemajuan teknologi pendidikan, keberhasilan Kegiatan Mengajar di sekolah khususnya di lingkungan Sekolah Dasar tidak hanya ditentukan oleh faktor pengajaran yang bersumber dari buku materi saja. Melainkan sudah mulai mengarah dalam pemanfaatan sumber informasi dari internet dalam memperkaya dan memperluas sumber bahan ajar. Peran guru dalam memperluas cakralawa ilmunya dinilai sangat penting untuk terus dikembangkan dan ditingkatkan. Pemanfaatan internet dapat mempermudah bagi guru untuk lebih berkreasi dalam pengembangan inovasi materi pelajaran di kelas. Sifat internet yang cair dan cepat melakukan perubahan secara dinamis menjadikan nilai informasi dan pengetahuan menjadi berkembang sangat cepat. Tidak bisa dipungkiri juga dengan segala aspek positif yang dimiliki oleh internet terkandung juga aspek negatif. Peran dari guru harus lebih mengetahui dampak negatif dan positif dari internet agar bisa menyampaikan dengan baik kepada siswa-siswanya di kelas. Bagaimana ruang yang tersedia di internet juga bisa dimanfaatkan para guru untuk bisa bertukar pemikiran dan berkomunikasi baik melalui email, forum diskusi, webblog maupun sosial media. Dari penelitian ini nantinya akan diperoleh pola pemetaaan dan komparasi bagaimana kemampuan guru di MI Al Madarijut dalam pemanfaatan media internet sebagai tambahan sumber materi pelajaran.
\end{abstract}

Kata kunci: Guru, Bahan Ajar, Belajar Mengajar, Pembelajaran, Internet

\begin{abstract}
Along with the advancement of educational technology, the success of teaching activities in schools, especially in elementary schools, is not only determined by the teaching factors originating only from material books, but also by the utilization of information resources from the internet in enriching and expanding the source of teaching materials. The role of teachers in expanding their knowledge is considered very important to be continuously developed and improved. The utilization of the internet can encourage teachers to be more creative in developing innovations in learning materials in classroom. The flexibility of the Internet and its quickness to dynamically produce changes make the values of information and knowledge grow very quickly. It cannot be denied that besides having the positive aspects, the internet has also negative aspects. Therefore, the teachers have to be more aware of the negative and positive impacts of the internet in order to be able to well explain them to the students in the class. The available space on the internet can be also used by teachers to exchange ideas and communicate through e-mail, discussion forums, web blogs and social media. The research will then give the mapping pattern and comparison of the competence of teachers in MI Al Madarijut in using the internet media as an additional source of subject materials.
\end{abstract}

Keywords: Teacher, teaching materials, Teaching-Learning, learning, the internet

\section{PENDAHULUAN}

Dalam rangka mengupayakan peningkatan kualitas guru, perlu pemanfaatan dan pendayagunaan sumber belajar yang lain, selain dari buku dan LKS, yaitu pemanfaatan internet untuk dapat menunjang dan mengoptimalkan Kegiatan Mengajar. Untuk bisa mewujudkan kualitas Kegiatan Mengajar tersebut, perlu ditempuh upaya yang masif dan komprehensif untuk meningkatkan kualitas guru terutama dalam memanfaatkan internet sebagai salah satu sumber yang bisa dijadikan materi dalam Kegiatan Mengajar. Bahan ajar adalah seperangkat sarana atau alat pembelajaran yang 
berisikan materi pembelajaran, metode, batasan-batasan dan cara mengevaluasi yang didesain secara sistematis dan menarik dalam rangka mencapai tujuan yang diharapkan, yaitu mencapai kompetensi atau subkompetensi dengan segala kompleksiasnya [1[. Pengertian ini menjelaskan bahwa suatu bahan ajar haruslah dirancang dan ditulis dengan kaidah instruksional karena akan digunakan oleh guru untuk membantu dan menunjang proses pembelajaran. Bahan atau materi pembelajaran pada dasarnya adalah "isi" dari kurikulum, yakni berupa mata pelajaran atau bidang studi dengan topik/subtopik dan rinciannya [2].

Berdasarkan isu yang berkembang, KBM di sekolah belum berjalan efektif dan maksimal, bahkan banyak guru yang mengajar tanpa memanfaatkan sumber belajar yang ada. Pola mengajar guru tersebut masih berparadigma teacher centris. Perkembangan dan informasi yang sangat pesat memungkinkan guru harus belajar menggunakan dan memanfaatkan internet sebagai sumber materinya. Ironisnya, banyak guru saat ini yang belum menguasai internet dengan baik, padahal siswa didiknya sudah banyak yang sehari hari terbiasa menggunakan internet. Dengan kondisi demikian, sudah seharusnya guru mulai mengenal dan harus memanfaatkan teknologi internet sebagai sumber bahan mengajar. Kegiatan Belajar Mengajar/KBM merupakan cara penyampaian materi pelajaran atau pengetahuan oleh seorang guru kepada anak didik nya serta dapat mengelola lingkungan supaya anak didik bisa belajar dengan optimal, sehingga anak didik bisa mendapatkan pengetahuan dan wawasan yang luas.

Revolusi teknologi masa kini, khusus komputer dan teknologi internet telah mengubah cara berpikir yang sangat praktis dan efisien pada masyarakat kita khususnya dan dunia pada umumnya. Kita dihadapkan pada gerbang transisi berbasis teknologi, Saat ini dimana kecepatan penyampaian dan menangkap nilai informasi menjadi hal yang penting dalam rangka memajukan dunia pendidikan. Di masa sekarang masyarakat yang bergerak sangat dinamis atau menjelang era masyarakat dinamis yang kita harapkan bisa terwujud di tahun-tahun mendatang, perlu kiranya kita melakukan langkah persiapan secara optimal. Mengapa persiapan tersebut tidak dimulai dari sekarang juga? Dengan ilmu pengetahuan saja tidak lagi cukup, sebab kita saat ini berada dalam teknologi mobile, dan teknologi tanpa kabel, semua menuntut multimedialitas. Siap atau tidak pengajaran berbasis Teknologi Informasi dan Komunikasi. Sudah harus dimulai sejak sekarang. Memanfaatkan teknologi komunikasi dan informasi di sekolah menjadi salah satu upaya untuk meningkatkan mutu guru di Indonesia [3]. Media pengajaran bisa dijadikan penyalur pesan dan informasi dalam model pembelajaran. Media pembelajaran yang dirancang secara baik akan sangat membantu peserta didik dalam mencerna dan memahami materi pelajaran. Di era globalisasi dan informasi ini, perkembangan media pembelajaran juga semakin maju. Penggunaan Teknologi Informasi (TI) sebagai media pembelajaran sudah merupakan suatu tuntutan [4].

Dari penelitian ini, dapat diharapkan kemampuan guru dalam penguasaan internet sudah menjadi keharusan karena pengajaran berbasis internet bagi siswa didik di sekolah dasar sudah seharusnya digunakan. Untuk itu, para guru hendaknya sudah menguasai internet sebelum menerapkan pembelajaran tersebut pada siswa. Persiapan yang tidak kalah penting yaitu sarana komputer, koneksi internet dan kemauan untuk mengembangkan kemampuan serta adanya forum guru yang 
bisa bersama-sama mengembangkan pengetahuan dan materi di dunia internet.

Internet sebagai sumber informasi yang sangat cepat. Ada dua peran penting internet dalam dunia pendidikan, yaitu sebagai sumber materi dan informasi, internet mampu menyimpan berbagai sumber data dan informasi dalam jumlah yang sangat besar dan tidak ada batasan lagi. Bidang apa saja yang diminati pasti ada informasinya di Internet. Informasiinformasi ini jika dikelola oleh para pendidik bisa menjadi sumber ilmu pengetahuan. Hal ini dapat digunakan guru untuk membuat bahan ajar untuk proses Kegiatan Belajar Mengajar (KBM) di sekolah. Lebih lanjut, bagi siswa dengan pemanfaatan internet menjadikan suasana KBM menjadi lebih menyenangkan sehingga dapat memudahkan siswa untuk menyerap pengetahuan lebih baik.

\section{METODE}

Metode penelitian ini merupakan penelitian explanatory research atau confirmatory research, penelitian yang berusaha menjelaskan hubungan kausal antara variabel-variabel yang diamati dan diteliti melalui pengujian hipotesis yang telah dirumuskan. Penelitian ini dilakukan untuk membuktikan hipotesis yang dibangun dengan melakukan survei langsung. Dengan metode ini, penelitian dilakukan analisa kajian terhadap faktorfaktor yang mempengaruhi Pemanfaatan Internet sebagai sumber materi bahan ajar bagi guru. Dari kajian teori dan pengamatan yang telah dilakukan oleh peneliti, maka faktor-faktor tersebut adalah: 1) pemahaman dan penggunaan komputer dan internet, 2) kebutuhan dan tuntutan terhadap pengembangan proses belajar mengajar, 3) daya dukung Sekolah, dan 4) kemampuan sumber daya manusia (guru) di sekolah. Faktor-faktor tersebut didefinisikan sebagai variabel bebas (independent variable), sedangkan variabel terikatnya adalah kemampuan menggunakan internet untuk pembuatan materi mengajar. Konstelasi hubungan antar variabel digambarkan pada Gambar berikut ini.

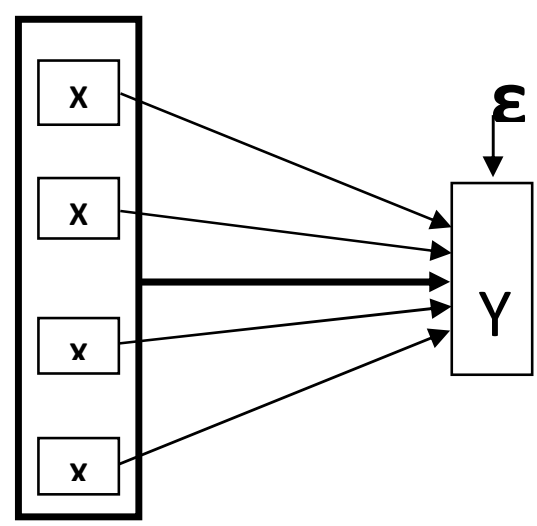

\section{Gambar 1. Konstelasi Hubungan Antar Variabel}

Keterangan:

Variabel Bebas $\left(\mathrm{X}_{1}\right)$ : pemahaman guru dalam pengunaan komputer dan internet

Variabel Bebas $\left(\mathrm{X}_{2}\right)$ : kebutuhan dan tuntutan terhadap pengembangan proses belajar mengajar

Variabel Bebas $\left(\mathrm{X}_{3}\right)$ : daya dukung sekolah Variabel Bebas $\left(\mathrm{X}_{4}\right)$ : kemampuan sumber daya manusia (guru) di sekolah Variabel Terikat (Y): kemampuan menggunakan komputer dan pemanfaatan internet.

\section{HASIL DAN PEMBAHASAN Deskripsi Data Penelitian}

Tabel 1. Deskripsi Data Penelitian

\begin{tabular}{lcccccc}
\hline \multicolumn{1}{c}{ Gender } & \multicolumn{7}{c}{ Usia (thn) } & & Jml \\
& 25 & $25-30$ & $30-35$ & $35-40$ & $>40$ & \\
\hline Pria & 1 & 1 & 0 & 3 & 2 & 7 \\
Wanita & 1 & 2 & 1 & 5 & 4 & 13 \\
Jumlah & 2 & 3 & 1 & 8 & 6 & 20 \\
Persentase & $10 \%$ & $20 \%$ & $5 \%$ & $40 \%$ & $30 \%$ & $100 \%$ \\
\hline
\end{tabular}


Deskripsi data secara deskripsi statistik sesuai hasil perhitungan yang dilakukan dengan bantuan komputer melalui program aplikasi SPSS 20. Untuk analisis dan intepretasinya adalah sebagai berikut:

Tabel 2. Deskripsi Data PenelitianDescriptive Statistics

\begin{tabular}{ccccc}
\hline & N & Min & Max & Mean \\
\hline Persepsi_Pemahaman_Komputer_dan_internet & 20 & 11.00 & 34.00 & 23.84 \\
Kebutuhan_dan_Tuntutan_Guru & 20 & 9.00 & 27.00 & 16.68 \\
Daya_Dukung_Sekolah & 20 & 28.00 & 67.00 & 51.20 \\
Kemampuan_SDM & 20 & 12.00 & 38.00 & 26.14 \\
Penggunaan_Komputer_dan_Internet & 20 & 24.00 & 75.00 & 52.26 \\
Valid N (listwise) & 20 & & & \\
\hline
\end{tabular}

Tabel 3. Deskripsi Data Penelitian

\begin{tabular}{cccccc}
\hline & N & $\begin{array}{c}\text { Banyaknya } \\
\text { Pertanyaan }\end{array}$ & $\begin{array}{c}\text { Skor } \\
\text { Maks per } \\
\text { butir }\end{array}$ & $\begin{array}{c}\text { Rata-rata } \\
\text { Skor per } \\
\text { butir }\end{array}$ & $\begin{array}{c}\text { Skor per } \\
\text { butir }\end{array}$ \\
\hline Persepsi pemahaman komputer \& internet & 20 & 10 & 5 & 2.383 & $47.68 \%$ \\
Kebutuhan_dan_Tuntutan_Guru & 20 & 8 & 5 & 2.085 & $41.70 \%$ \\
Daya_Dukung_Sekolah & 20 & 14 & 5 & 3.657 & $73.14 \%$ \\
Kemampuan_SDM & 20 & 10 & 5 & 2.614 & $52.28 \%$ \\
Penggunaan_Komputer_dan_Internet & 20 & 18 & 5 & 2.9033 & $58.07 \%$ \\
Valid N (listwise) & 20 & & & & \\
\hline
\end{tabular}

\section{Analisa Menurut Persentase \\ Keberagaman Jawaban Responden}

Pesentase keberagaman dalam hal ini menunjukkan tingkat keberagaman jawaban responden atas angket yang diberikan oleh peneliti. Rumus perhitungannya adalah:

$$
T K=\frac{S}{\bar{X}} \times 100 \%
$$

Keterangan:

$\mathrm{TK}=$ Tingkat keragaman

$\mathrm{s} \quad=$ simpangan baku

$\bar{X} \quad=$ rata-rata datable 4.3

Tabel 4. Rekapitulasi Hasil Pengujian NormalitasTests of Normality

\begin{tabular}{ccccccc}
\hline & \multicolumn{4}{c}{$\begin{array}{c}\text { Kolmogorov- } \\
\text { Smirnova }^{\text {S }}\end{array}$} & \multicolumn{3}{c}{ Shapiro-Wilk } \\
\hline & Stat & df & Sig & Stat & df & Sig \\
\hline Persepsi_pemahaman_komputer_dan_internet & .110 & 20 & .175 & .962 & 20 & .110 \\
Kebutuhan_dan_Tuntutan_Guru & .115 & 20 & .098 & .963 & 20 & .124 \\
Daya_Dukung_Sekolah & .112 & 20 & .158 & .962 & 20 & .112 \\
Kemampuan_SDM & .100 & 20 & $.200^{*}$ & .973 & 20 & .307 \\
Penggunaan_Komputer_dan_Internet & .100 & 20 & $.200^{*}$ & .978 & 20 & .455 \\
\hline
\end{tabular}

Pada tabel di atas terlihat bahwa nilai pada kolom Sig pada metode KolmogorovSmirnov untuk semua sampel lebih besar dari 0,05 , sehingga $\mathrm{H}_{0}$ diterima, dengan kata lain bahwa data dari semua sampel pada penelitian ini berdistribusi normal.

\section{Pengujian Linieritas Garis Regresi}

Pengujian linieritas di dalam penelitian ini memiliki hipotesis sebagai berikut:

$\mathrm{H}_{0}$ : Adanya garis regresi hubungan antara varibel $X$ dan variabel $Y$ linier

$\mathrm{H}_{1}$ : garis regresi hubungan antara varibel $\mathrm{X}$ dan variabel $\mathrm{Y}$ tidak linier 
Perhitungan dilakukan dengan bantuan komputer melalui program aplikasi SPSS 20. Menurut ketentuan yang ada pada program tersebut maka kriteria dari normalitas data adalah "jika $p$ value (sig)< 0.05 maka $\mathrm{H}_{0}$ diterima", yang berarti bahwa sampel-sampel inimengarah dari populasi yang homogen. Nilai $p$ value (sig) adalah bilangan yang tertera pada kolom sig baris Linierity dalam tabel informasi ANOVA dari hasil pengujian perhitungan linieritas garis regresi oleh program SPSS. Hasil perhitungan pengujian linieritas garis regresi hubungan antara variabel $X_{1}$ dengan variabel $\mathrm{Y}$ terdapat pada Tabel 5.

Tabel 5. Rekapitulasi Hasil Pengujian Linieritas Garis Regresi Pengaruh Variabel X terhadap Variabel Y

\begin{tabular}{ccccccc}
\hline & & $\begin{array}{c}\text { Sum of } \\
\text { Squares }\end{array}$ & df & $\begin{array}{c}\text { Mean } \\
\text { Square }\end{array}$ & F & Sig. \\
\hline $\begin{array}{c}\text { Persepsi_pemahaman_ } \\
\text { komputer_dan_internet } \\
\text { Kebutuhan_dan_ } \\
\text { Tuntutan_Guru }\end{array}$ & $\begin{array}{c}\text { Deviation from } \\
\text { Linearity } \\
\text { Deviation from } \\
\text { Linearity }\end{array}$ & 1712.492 & 22 & 77.841 & .815 & .685 \\
Daya_Dukung_Sekolah & $\begin{array}{c}\text { Deviation from } \\
\text { Linearity } \\
\text { Deviation from } \\
\text { Linearity }\end{array}$ & 1663.774 & 24 & 69.324 & .686 & .819 \\
Kemampuan_SDM & 1991.336 & 23 & 86.580 & .779 & .725 \\
\hline
\end{tabular}

Pada tabel di atas terlihat bahwa nilai pada kolom Sig untuk semua pengaruh variabel bebas $X$ terhadap variabel terikat $Y$ lebih besar dari 0,05 , sehingga $\mathrm{H}_{0}$ diterima.
Dengan kata lain bahwa semua garis regresi yang tebentuk dari pengaruh variabel bebas $X$ terhadap variabel terikat $Y$ tersebut linier.

Tabel 6. Rekapitulasi Hasil Pengujian Koefisien Korelasi Pengaruh Variabel X Secara Partial terhadap Variabel Y

\begin{tabular}{cccc}
\hline & & Koefisien \\
& Korelasi & Koefisien \\
Dersepsi_pemahaman_- & Pearson Correlation & $.671^{* *}$ & \\
komputer_dan_internet & Sig. (2-tailed) & .000 & $45.02 \%$ \\
Kebutuhan_dan_Tuntutan_Gurusi & N & 20 & \\
& Pearson Correlation & $.581^{* *}$ & $33.76 \%$ \\
& Sig. (2-tailed) & .000 & \\
Daya_Dukung_Sekolah & N & 20 & \multirow{2}{*}{$46.38 \%$} \\
& Pearson Correlation & $.681^{* *}$ & \\
Kemampuan_SDM & Sig. (2-tailed) & .000 & \\
& N & 20 & $37.45 \%$ \\
& Pearson Correlation & $.612^{* *}$ & \\
& Sig. (2-tailed) & .000 & \\
& N & 20 & \\
& Pearson Correlation & $.681^{* *}$ & \\
& &
\end{tabular}

Dari tabel di atas terlihat bahwa semua koefisien korelasi yang terbentuk dari masing-masing pengaruh variabel $\mathrm{X}$ terhadap variabel terikat $\mathrm{Y}$ secara partial signifikan pada taraf nyata $1 \%$, hal ini menunjukkan bahwa masing-masing variabel bebas $\mathrm{X}$ tersebut (persepsi pada komputer dan internet, kebutuhan dan tuntutan guru pada komputer dan internet, daya dukung sekolah, dan kemampuan SDM) secara signifikan berpengaruh secara partial terhadap terikat Y (Tingkat Penggunaan komputer dan internet). Sedangkan koefisien determinasi masing- 
masing pengaruh variabel bebas $\mathrm{X}$ terhadap variabel terikat $\mathrm{Y}$ secara partial yang besarnya kontribusi masing-masing variabel bebas $\mathrm{X}$ terhadap variabel terikat Y secara partial bisa dilihat pada kolom terakhir pada Tabel 6. di atas.

\section{Tabel 7. Rekapitulasi Hasil Pengujian Koefisien Korelasi Ganda PengaruhSemua Variabel X secara bersama-sama terhadap Variabel YModel Summary ${ }^{b}$}

\begin{tabular}{|c|c|c|c|c|}
\hline Model & $\mathrm{R}$ & R Square & $\begin{array}{l}\text { Adjusted R } \\
\text { Square }\end{array}$ & $\begin{array}{l}\text { Std. Error of the } \\
\text { Estimate }\end{array}$ \\
\hline 1 & $.812^{\mathrm{a}}$ & .660 & .630 & 7.59203 \\
\hline \multicolumn{5}{|c|}{$\begin{array}{l}\text { a. Predictors: (Constant), Kemampuan_SDM, Persepsi_pada_-_ } \\
\text { komputer_dan_internet, Kebutuhan_dan_Tuntutan_Guru, } \\
\text { Daya_Dukung_Sekolah }\end{array}$} \\
\hline
\end{tabular}

Dari Tabel 7. di atas bisa dilihat bahwa koefisien korelasi ganda terjadi pada semua variabel bebas $\mathrm{X}$ yang bersamasama terikat variabel $\mathrm{Y}$ adalah sebesar 0,812 , dan signifikan pada taraf nyata $1 \%$, yang berarti bahwa memang ada pengaruh semua variabel bebas $\mathrm{X}$ (persepsi pada komputer dan internet, kebutuhan dan tuntutan guru, daya dukung sekolah, dan kemampuan SDM) secara signifikan berpengaruh secara bersama-sama terhadap terikat $\mathrm{Y}$ (Tingkat Penggunaan komputer dan internet).

Dari pengujian hasil diperoleh $\mathbf{F}_{\text {hitung }}=$ 21.842 lebih besar dari $\mathbf{F}_{\text {tabel, dimana nilai }}$ Ftabel untuk n (jumlah data) $=50, \mathrm{k}$ (banyaknya variabel bebas) $=4$, dan taraf nyata $=5 \%$ adalah 5,57. Demikian juga jika perhatikan nilai Sig, semuanya kurang dari 0,05. Hal tersebut berarti untuk hipotesis $5, \mathrm{H}_{0}$ ditolak dan $\mathrm{H}_{1}$ diterima, dengan kata lain bahwa memang terdapat pengaruh yang signifikan semua vaiabel bebas $\mathrm{X}$ (persepsi pemahaman pada komputer dan internet, kebutuhan dan tuntutan guru pada komputer dan internet, daya dukung sekolah, dan kemampuan SDM pada komputer dan internet) secara bersama-sama terhadap variabel terikat $\mathrm{Y}$ (Tingkat Penggunaan komputer dan internet). Dari hasil analisa regresi dapat disimpulkan bahwa semua variabel bebas (persepsi pemahaman pada komputer dan teknologi internet, kebutuhan dan tuntutan guru pada komputer dan internet, daya dukung sekolah, dan kemampuan SDM pada komputer dan internet) semua berpengaruh positif dan signifikan secara bersama-sama terhadap variabel terikat $\mathrm{Y}$ (Tingkat Penggunaan komputer dan internet).

\section{SIMPULAN}

Berdasarkan deskripsi data penelitian dan setelah dilakukan analisis serta pengujian maka dapat disimpulkan:

1. Terdapat pengaruh yang positif dan signifikan semua variabel bebas $\mathrm{X}$ (persepsi pemahaman pada komputer dan internet, kebutuhan dan tuntutan guru pada komputer dan internet, daya dukung sekolah, dan kemampuan SDM pada komputer dan internet) terhadap variabel terikat Y (Tingkat Penggunaan Komputer dan internet) baik secara bersama-sama.maupun secara partial.

2. Masih rendahnya tingkat penerimaan dan penggunaan komputer dan internet di sekolah (58.07\%) disebabkan karena rendahnya kebutuhan dan tuntutan guru pada penggunaan komputer dan internet 
$(41.70 \%)$ dan rendahnya persepsi pemahaman guru pada komputer dan internet $(47.68 \%)$.

3. Rendahnya kebutuhan dan tuntutan guru pada penggunaan komputer dan internet lebih dikarenakan responden yang telah berusia diatas 35 tahun $70 \%$ yang mempengaruhi dari rendahnya pemahaman terhadap komputer dan internet serta rendahnya kebutuhan guru terhadap komputer dan internet dan pemahaman terhadap komputer dan internet.

4. Daya dukung sekolah dan kemampuan SDM di sekolah sangat memungkinkan untuk meningkatkan penerimaan dan penggunaan komputer dan internet di sekolah baik untuk pengembangan inovasi pelajaran maupun untuk kegiatan administrasi sekolah.

\section{DAFTAR PUSTAKA}

[1] Lestari, Ika. Pengembangan Bahan Ajar Berbasis Kompetensi: sesuai dengan KTSP. Padang: Akademia Permata, 2013.

[2] Ruhimat, Toto, dkk. Kurikulum dan Pembelajaran. Jakarta: PT Raja Grafindo Persada, 2011.

[3] W. Purnomo. Pembelajaran Berbasis ICT. Inovasi Dalam Pendidikan, pp. 11-14, 2008.

[4] A. Muhson. Pengembangan Media Pembelajaran Berbasis Teknologi Informasi. Jurnal Pendidikan, vol. 8, no. 2, pp. 1-10, 2010. 